\title{
Book Reviews / Revue de livres
}

Peat: Industrial Chemistry and Technology. Charles H. Fuchsman, Academic Press, New York, 279 p., 1980 US $\$ 28.00$.

The value of peat as an agricultural/horticultural soil amendment or as a fuel is well recognized. What about other uses? Fuchsman's well-referenced book is an exceptional literature review, global in extent, which describes a variety of end uses for peat based on chemical properties rather than physical properties.

Peat resources of several countries are summarized in the introduction. Reference is made to Canada's resource as being considerable, but, in the absence of an intensive inventory, only 348 bogs (greater than $40 \mathrm{ha}$ ) are recognized as being exploitable. The chemical/biological interrelationships of peats, methods of peat classification, and the ecosystemic relationships with the natural process of peat formation are clearly described in layman's terms.

On the more technical side, the text details, among other things, the processing methodology and the products and byproducts obtainable through solvent extraction of peat bitumens (resins, asphaltic materials, peat waxes, steroids, etc.). The partitioning of chemical complexes of peats by hydrolysis to produce various carbohydrates, yeasts, and organic chemicals is explained. Medicinal products as

"Torfot" used in the treatment of ophthalmic diseases, obtained from peat are summarized in Chapter 11 , citing mainly Soviet sources. The extraction methodology and potential uses of a variety of humic acids are well described. The economic possibilities of peat lignins,

the residual organic material after bitumens, hemicelluloses, humic acids, and celluloses have been removed...", has been surmised even though they have not been extensively studied.

The production of charcoal, semi-coke, and coke, from peat is described giving examples of processes used in the USSR, Finland and Germany. The low phosporus, sulfur, calcium and ash contents of some peats make them desirable as a raw material for coke production. Peat coke is a highly specialized product used in metallurgy where coal coke is considered too impure. Activated carbon can also be produced from peat

One chapter is devoted to methods of peat analysis. The final chapter briefly describes the possible environmental detriment caused by industrial production of the various materials described. However, as these would be rather small scale, their impact could readily be minimized.

Considering the extent of the peat resource in Canada and the numerous products capable of being produced from peat, serious consideration should be given to capitalizing on our peatlands.

\section{V.F. Haavisto}

Great Lakes Forest Research Centre Sault Ste. Marie, Ontario

Les forêts du Témiscamingue, Québec: écologie et photo-interprétation. JeanLouis Brown, Université Laval, Laboratoire d'écologie forestière, Québec, Études écologiques, 447 p., 1981, $\$ 12.00$.
Le travail de Jean-Louis Brown doit être considéré comme ce qu'on appelait au début du siècle une "Somme". C'est d'ailleurs le cas de l'ensemble des travaux publiés dans la série "Études écologiques'"

"Les Forêts du Témiscamingue" représente le fruit d'une connaissance approfondie du terrain et est le résultat de très nombreuses heures de travail. Ce livre pourrait être la bible de tout aménagiste ayant à oeuvrer dans la forêt feuillue du sud du Témiscamingue. II décrit et identifie avec précision 23 associations et 13 sous-associations. Bourrée de données chiffrées sur les caractéristiques dendrométriques et les sols des forêts du Témiscamingue, l'intérêt local de l'étude est cependant transcendé par une analyse du dynamisme des peuple. ments. Les forêts du Témiscamingue étant, comme le dit l'auteur, "parmi les plus vieilles et les plus intactes du Québec méridional", elles se prêtent bien à une analyse du dynamisme des écosystèmes et des effets de cette évolution sur la structure et la productivité des peuplements forestiers.

Le livre est bien construit. Après avoir exposé certaines notions de base, telles que les caractéristiques photo-interprétatives et écologiques du milieu et des peuplements, l'auteur précise la méthodologie suivie et définit le cadre écologique et les ensembles végétations-sol. Lors des discussions et de la synthèse, de nombreuses comparaisons sont faites entre les caractéristiques pédologiques et les groupements climaciques ou de transition.

L'utilité locale d'un tel ouvrage réside non seulement dans la description des associations mais également dans le lien qui est fait entre la photo-interprétation et l'écologie, au sens large, des peuplements. L'auteur démontre l'importance du mésorelief dans la distribution de la végétation et celle du mésoclimat dans la croissance. L'épaisseur des dépôts superficiels semble également être un facteur déterminant pour la distribution de la végétation et son dynamisme. Les perturbations, naturelles et humaines, que subit la forêt sont responsables des séquences chronologiques de la végétation et justifient la nécessité d'une connaissance exacte de l'état actuel d'un peuplement et de sa position dans la chronoséquence avant qu'une intervention soit envisagée. Ainsi, l'étude du dynamisme particulier à chaque peuplement permet de prendre des décisions d'aménagement éclairées. Les données sur la vitesse de croissance manquent cruellement aux aménagistes et Jean-Louis Brown apporte de nombreuses réponses dans le cas des essences feuillues du Témiscamingue.

L'ouvrage est illustré de belles photographies en couleur qui nous montrent des peuplements d'une qualité que peu de forestiers ont l'occasion de rencontrer au Québec. Une série de stéréogrammes figurent en annexe et illustrent les différents peuplements, leurs caractéristiques forestières et le type de dépôts du point de vue du photo-interprète forestier.

En résumé, un "gros" livre, long à lire, mais qui a la valeur d'un dictionnaire pour tout forestier oeuvrant dans les forêts du Témiscamingue.

Gilles Frisque,

Centre de Recherches forestières

des Laurentides.
Postwar Trends in US Forest Products Trade - A Global, National, and Regional View. Roger A. Sedjo and Samuel J. Radcliffe, Resources for the Future, Inc., Washington, D.C., Research Paper R-22, 595 p., 1981, US $\$ 15.00$ paperback. ISBN 0-8018-2635-7

This book should be read carefully with the expectation of gaining sharper insights into and deeper understanding of the future of Canada's position in World forest products trade. Sedjo is a senior fellow of RFF's Forest Economics and Policy program. Radcliffe undertook research in forestry and forest economics issues for RFF before joining a forestry consulting firm in Milwaukee, Wisconsin as a resource analyst. They researched the future US role in the world forestry economy, examining the global structure of forest products, production and trade and recent US regional and national contributions. Their study has met its objectives which were to organize available data to a usable form, provide a comprehensive overview of international trade in forest products, describe and analyse the global and regional roles of the United States, and provide other researchers with a sound point of departure for further work. In 142 pages, six chapters introduce and interpret material based on sample years 1950 to 1976 . Thirteen appendices provide much regional detail in 433 pages, which represent each year 1967 to 1976. US imports and exports are recorded by quantity and value for thirteen commodities for the major regions of origin and foreign country destinations.

My interest in forest products trade was whetted by a 1965 seminar that I helped organize on "British Columbia's future in forest products trade in Asia and the Pacific area". A special address by John Zivnuska published in that seminar Proceedings marked the beginning of a widening US awareness of the importance of internatinal trade in forest products. Dr. Zivnuska's paper "On defining the role of the United States in a world timber economy", was followed in 1967 by his RFF book on "US timber resources in a world economy". Since then, US evaluations of timber trends and trade prospects have paid increasing attention to international trade. Some foresters and industrialists even believe that the United States has the potential to become the "wood basket" of the World.

In the period 1950-76, Canadian forest products trade surplus grew almost continuously while US forest products trade declined modestly in real value. With so much of the Canadian exports of forest products moving to the United States in "normal" times, Canadians should make major efforts to monitor, understand and influence all of the factors that can be changed to improve our trade relationships. Although up-dating of this study is urgently needed, it stands now as a thorough documentation of postwar trends and as a foundation for even better studies in the future.

\author{
J. Harry G. Smith, \\ Faculty of Forestry, \\ University of British Columbia.
}


A History of English Forestry. N.D.G. James, Blackwell, Oxford, 339 p., 1981, $\$ 68.25$ in Canada through Oxford University Press, Don Mills, ON. ISBN 0-631-12495-0. (£19.50 in UK, $£ 12.00+£ 1.00$ postage to members of the Royal Forestry Society.)

Foresters! How many of the following forestry-related terms can you define? agister, amerce, assart, bercelet, berner, blestro, botes, brache, brimming, cablish, charke, cheminage, dotard, drift of forests, essoins, estovers, ferm, fermisone, fewterer, fire-bote, hombling, hoxing, imparking, launds, lawing of dogs, lymer, mainpernors, metes, palester, pawnage, pilchers, pinguedo, pourallee, poutura, purpresture, puture, rache, ramell, restnauger, robura, scarfing, scotale, sny, squillectes, turbary, vaccaries, velters, ventrer, vert, wrassels, and yeld? How many of them have you heard of? James brings these seemingly Carrol-esque terms, and others, to life in this scholarly, beautifully written book, which he has dedicated to the Royal Forestry Society of England, Wales, and Northern Ireland in commemoration of its centenary, 1882-1982. It is a worthy tribute.

The book covers the 900 years from the Normans (1066 and All That) to the present day.

The first of two parts of the book deals with the medieval forests. It is here that the reader will meet most of the terms listed in the opening paragraph of this review. More than half of Part One consists of descriptions, chiefly of a topographical nature, of 129 ancient forests and chases. A chase, by the way, was similar to a forest inasmuch as it was unenclosed and defined by metes and bounds, but it differed from a forest in two main respects: it could be held by someone other than the king and it was not subject to forest law. This ownership distinction made by James is puzzling in that, in the previous paragraph, he had noted that while "some of the land in a forest might belong to the king much of it belonged to his subjects."

These descriptions of the mediaeval forest will be of interest mainly to those who have personal acquaintance with the forests, yet they abound with nuggets of in. terest: included in the account of Sherwood Forest, for instance, is a reference to the "somewhat mythical figure" of Robin Hood. James cites Leland, who travelled through Yorkshire during the reign of Henry VIII: "Along on the left hand a iii miles of betwixt Milburne and Feribridge I saw the woodi and famose Forest of Barnesdale wher they say that Robyn Hudde lyvid like an outlaw." James points out that the distance between Ferrybridge and the closest part of Sherwood Forest was "only" 38 miles $(61 \mathrm{~km})$ as the crow flies, which might not have prevented a resourceful outlaw from operating in both areas.

Part Two, the Development of Modern Forestry, is longer than the first. Its opening sentence is one that should produce a jolt of recognition in every Canadian forester: "By the beginning of the sixteenth century, the structure of the medieval forests had begun to crumble despite the fact that the facade was to remain for another hundred years" (emphasis added). The chapter headings in this part reveal James' treatment of his subject: The Overture to Forestry (including another observation by
Leland that "Many hills thereabout hath bene well woddid... but now in them is almost no woode."); The Wooden Walls (including knees, strakes, futtocks, and wal ing); The Old Forestry (and the development of nursery practice and artificial regeneration); The New Forestry (and the emergence of a new interest in forestry, as evidenced by the founding of the Scottish Arboricultural Society (now the Royal Scottish Forestry Society) in 1854, and the English Arboricultural Society (now the Royal Forestry Society....) in 1882; The First World War and its Aftermath (and the establishment of the Forestry Commission): The Second World War (in which "forestry units of the British, Australian, New Zealand and Canadian Armies played an important part in the felling and conversion of timber"); The Post-War Era; and The Changing Scene. There are also several useful appendices.

If anyone should be under the delusion that history is dull, this book could not fail to relieve that condition. History can be a great teacher given the chance, and there are important lessons to be learned from this book not only by Canadian foresters but also by Canadian politicians. This thorougly enjoyable book has a serious message for any Canadian who has the wit to see it.

\section{R. F. Sutton}

Man and the Mediterranean Forest: A History of Resource Depletion. J. V. Thirgood, Academic Press, London, $194 \mathrm{p}$. $1981, \$ 29.00$ ( $£ 12.00$ in UK). ISBN 0.12 .687250 .3

This slim, erudite yet readable book can be read at a number of levels, and by a range of reader groups. It will inform them all.

For the forester it is a detailed account of the destruction of once-productive forests in the Mediterranean basin by over-exploitation and mismanagement - " . . . the whole economy of the forest was deranged Although conditions there are very different from those of the Pacific North-West some telling passages are not inapplicable here:

forest technology is not inadequate implementation has been deficient:" and

less desirable and small woods led to the development of special working techniques." Mention of fuel shortages too has a familiar ring. As one who is unhappy with the regular application of the term "balsam fir" to a component species of forest in which Abies balsamea does not occur, I was wryly amused at the confusion which arose from misuse or misapplication of common names and the consequent difficulties of translation and interpretation. The author's depth of historical background and broad perspective illustrates well the difference between a viewpoint that is truly professional and not merely technological.

Social historians will find a readable summary of the development of civilizations and communities in this the focal point of our modern society, and will be led to consider the intimate relationship between environment and a society's development. What will they make of the claim that "... the destruction of the Mediterranean forest has been part of the price of the development of western civilization"?

Every politician who is concerned in any way with land management should be called on to study at least the final 12 summarizing pages. The potent phrase "the chain of ecological cause and effects begins with the management of land" should be included in their daily litany.

For the pastoralist the dramatic and awful warning is reiterated - " .... Indiscriminate felling, burning, the browsing of goats and other animals, combined with faulty agricultural practices, have virtually exterminated the natural forest and degraded the soil that supported it." And for the agricultural advisors we find the most daunting of challenges ". ... the first priority is to change attitudes ..." set alongside the requirement that ". . . animal husbandry should be revolutionized...". Those advisors will be well advised themselves to take cognizance of the pervasive ill-effects on society of a shortage of fuelwood and the effect of lack of timber on the standard of living of rural populations.

The philosophical debater can tackle the not incontrovertible premise that "environmental destruction was a necessary precursor of development of a civilization' or the paradox that while increasing urbanization is the solution to the problem of increasing rural pressure it was also a major factor in the decline of early civilizations. Another debating point, this one for the ecologist, is the reference to R. O. Whyte's questioning of the value of climax as concept useful to land managers.

In chronicling the destruction of forests and spoliation of the Mediterranean lands from Soloman and biblical times through the eras of the Greeks and Romans, the Islamic and Ottoman hegemonies and right up to the present day, Dr. Thirgood has shown that "... the fault... is not in our stars but in ourselves...", that we cannot blame climatic change for the environmental degradation which is all too obvious today. Mankind, and especially the unregulated pastoralist, is largely to blame, but the situation is not without hope. Given a stable, far-sighted administration and popular support, a dedicated trained staff can halt or prevent the tragedy. We had better comprehend his story, or it will not be only the Levantines for whom timber will become a "luxury item".

With only a very few and unimportant flaws this is a readable account, replete with many useful potential quotations, but at some $\$ 29.00$ it is discouragingly pricey. That's a pity, because the message is timely and needed.

\section{R. M. Strang}

Forest Research Council

Province of British Columbia

Richmond, BC

The Pesticide Manual. A World Compendium. 6th Ed. Charles R. Worthing (Ed.), British Crop Proctection Council, Croydon, England, 665 p., 1979, US $\$ 65.00$. ISBN 0-901436-44-5. Available from International Scholarly Book Services Inc., Box 1632, Beaverton, Oregon 97075. 
The first edition of The Pesticide Manual dates from 1968. This 6 th edition (reprinted in 1980) builds on a solid foundation. The editor, the managing editor, and the advisory editorial board have used well their wealth of knowledge and experience, to improve still further an already excellent publication.

Dr. Worthing (Glasshouse Crops Research Institute) notes in the Preface that the intention has been to include all chemicals and microbial agents used as active components of products to control pests and diseases, pests in public health, and animal ectoparasites. Details of herbicides, plant growth regulators, and pest repellents are also included.

The changes introduced in the 6 th edition include the use of boldface subheadings within each entry as a very effective aid to speed the location of subject matter of interest, and there are now four indexes: Wiswesser Line-Formula Notation (WLN): molecular formula; code numbers of compounds (both manufacturers' and institutional, etc.); and a name index covering chemical names, trivial names, common names, and trade marks. The WLN, by the way, is a string of symbols constructed by strict rules to provide in linear form a compact, unique, and unambiguous description of a molecular structure, such descriptions being useful in manual and computer-based indexing and retrieval systems.

Each of 551 compounds, arranged alphabetically by the British Standards Institution common name, is described on a separate page. The format adopted is extremely clear and to the point. The only adverse comment I would offer is that the use of " 1 " is less clear as a symbol for litre than "L" would have been. The information given includes common names, current and former Chemical Abstracts names, discovering organization or person, trade marks, early important scientific references, manufacturing process, physical and chemical properties of the active ingredient and/or the technical product, principal uses, oral and dermal $L_{50}$ values, chronic toxicity, toxicity to wildlife, principal formulations, and methods of analysis.

The Appendices include a useful listing of "superseded compounds" that, though at one time marketed or widely reported, are believed to be of little current commercial interest in the context of The Pesticide Manual. There is also a list of scientific and common names of animals quoted in the toxicology section of entries, though authorities are omitted. Addresses of firms and details of books mentioned in the text are appended separately.

As a point of interest, the 16 member organizations of the British Crop Protection Council include: the Association of Applied Biologists, the British Agricultural Research Council, Natural Environment Research Council, Department of the Environment (Great Britain), and the Agricultural Science Service.

The Pesticide Manual can be highly recommended to anyone interested in any aspect of pesticides. The price is steep, but in every way, from binding to contents, this is a book of exceptionally fine quality.
Growth of Forests in Canada, Part 2: Quantitative Description of the Land Base and the Mean Annual Increment. A. Bickerstaff, W. L. Wallace, and F. Evert. Environment Canada, Canadian Forestry Service, Inf. Rep. PI-X-1, 136 p., 1981.

Part 1 of the study of the Growth of Forests in Canada was an annotated bibliography and historical review of growth and yield studies in Canada (prepared by $A$. Bickerstaff and S. Hostikka in 1977). This Part 2 report presents a national overview of the preliminary estimates of the productive capacity and growth for Canada's forests by 139 ecological and political subdivisions. The publication is an excellent, well presented, and well illustrated sum. mary of benchmark data on forest produc. tivity at the national and regional levels.

The casual reader of this report might be tempted to be critical where criticism is not warranted. For example, there are many forested areas of British Columbia that would have "poor access and/or stand operability" ratings that are not shown as such on map 6 in the report. It must be recognized, however, that these kinds of areas cannot be identified at the national overview level because of the high degree of generalization of the data and the small scale of the maps used in the report. The authors stress that the information presented is inadequate for site-specific forest management planning.

The report includes chapters on Growth Concepts and Definitions, Forest Classification Concepts, Methodology and Data Bases, Growth, and Area Statistics (summarized by National Overview, by Forest Regions, and by Provinces and Territories), Evaluation and Comparison of Basic Statistics, Growth, Allowable Cut and Annual Depletion, and Growth and Improved Forest Management.

Anyone who has attempted to summarize and compare forestry and forest land data at a national or regional level is soon aware of the deficiencies and weakness in the data bases that are available, both in published and unpublished form. The authors of this report have been very thorough in outlining the many assumptions and qualifications that, of necessity, must accompany their data presentations and comparisons.

In summary, this report is a valuable contribution to an understanding of our national forest resource base. Improvement in these first approximations are desirable, and it is hoped that the formation and recommendations outlined in this report will stimulate efforts to revise them in future years.

\section{S. Lacate}

Lands Directorate

Environment Canada

Vancouver, BC

\section{R. F. Sutton}


RESOURCE ECONOMICS

\section{IN FOREST \\ FACULTY POSITION}

\section{Department of Forestry and Resource Management UNIVERSITY OF CALIFORNIA Berkeley}

Position - Pending budgetary approval, the position will be filled at the assistant professor level at a salary between $\$ 23,800$ and $\$ 28,500$ per year, depending on the qualifications of the individual. Appointment will be on an 11 months per year basis, with the duties half in teaching and half in research.

Qualifications - Applicants must have a degree in forestry, either at the bachelor's or master's level, and a Ph.D. with specialization in forest resource economics. Doctoral candidates expecting to complete the degree by the end of 1982 are encouraged to apply.

Responsibilities - (a) Teaching duties include an undergraduate course and a graduate course in forest resource economics and a third course to be assigned on the basis of departmental needs. (b) Research responsibilities will be in the general area of forest resource economics, with specific duties selected by mutual agreement between the appointee and the Department. Excellent opportunities exist for work in cooperation with governmental agencies and private companies.

Applications - Applications will be considered if received prior to April 15, 1982. Applications received after that date will be considered only if the results of the initial search are inconclusive. A letter of application, resume, list of publications, academic transcripts, and the names of three or more persons as references should be sent to:

Chairman of Search Committee

(Forest Resource Economics)

Department of Forestry and

Resource Management

145 Mulford Hall

University of California

Berkeley, California 94720

Interested persons are invited to obtain additional information on the position by calling collect to:

(415) 642-0376

THE UNIVERSITY OF CALIFORNIA IS AN EQUAL OPPORTUNITY, AFFIRMATIVE
FACULTY POSITION IN WILDLAND FIRE MANAGEMENT

Department of Forestry and Ressource Management UNIVERSITY OF CALIFORNIA Berkeley

Position - Pending budgetary approval, the position can be filled at the assistant or associate professor level, depending on the qualifications of the individual. Appointment will be on an 11 months per year basis, with the duties half in teaching and half in research.

Qualifications - Applicants must have a Ph.D. degree with specialization in wildland fire management. Preference will be given to applicants with either the B.S. or Master's degree in forestry. Areas of expertise may include fire management, wildland fire ecology, computer modeling, and optimization techniques. Applicants should have a strong interest in conducting a program of original research. Doctoral candidates expecting to complete the degree by the end of 1982 are encouraged to apply.

Responsibilities - (a) Teaching, including an undergraduate course in control and management of fire, a graduate course in fire as an ecological factor in forest management, and a third course to be assigned on the basis of departmental needs. (b) Research, including duties in such areas as use of fire in forest stands as a means of controlling composition and structure; characteristics of forest fuels and methods of reducing accumulations of forest fuels: costs of using and controlling fire in the wildland environment; and effects of fire on wildland environment.

Appointment - The position is available July 1,1982 , but the reporting date is open to negotiation. The Department plans to fill the position with the applicant believed to have the highest potential for developing leadership in wildland fire management, without regard to the level of appointment for which the selected applicant is qualified.

Applications - Applications will be considered if received prior to April 15,1982 . A letter of application, resume, list of publications, academic transcripts, and the names of three or more persons as references should be sent to:

Chairman of Search Committee

(Wildland Fire Management)

Department of Forestry and

Resource Management

145 Mulford Hall

University of California

Berkeley, California 94720

Interested persons are invited to obtain additional information on the position by calling collect to:

(415) 642-0376

THE UNIVERSITY OF CALIFORNIA IS AN EOUAL OPPORTUNITY. AFFIRMATIVE

EOUAL OPPORTUNITY. AFFIRM
ACTION EMPLOYER. 